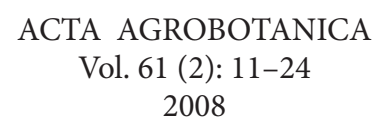

\title{
STRUCTURE OF KALANCHÖ̈ PUMILA BAK. LEAVES (CRASSULACEAE DC.)
}

\author{
Mykhaylo Chernetskyy ${ }^{1}$, Elżbieta Weryszko-Chmielewska ${ }^{2}$ \\ ${ }^{1}$ Botanical Garden, Maria Curie-Skłodowska University in Lublin, Sławinkowska 3, 20-810 Lublin, Poland \\ e-mail: sedum@o2.pl \\ ${ }^{2}$ Department of Botany, University of Life Sciences in Lublin, Akademicka 15, 20-950 Lublin, Poland \\ e-mail: elzbieta.weryszko@up.lublin.pl
}

Received: 19.09.2008

\section{$\mathrm{S} \mathrm{u} \mathrm{m} \mathrm{m} \mathrm{a} \mathrm{r} \mathrm{y}$}

The structure of Kalanchoë pumila Bak. was studied with the use of stereoscopic, light, scanning and transmission electron microscopy. It was found that the chlorenchymatic tissue was divided into subepidermal small-celled mesophyll and large-celled (water transporting, CAM type) mesophyll, placed in the central part of the leaf. The mesophyll structure and its cell ultrastructure indicate $\mathrm{C}_{3}$ photosynthesis in this taxon, whereas CAM photosynthesis, being an adaptive syndrome, is induced by external factors.

Three groups of xeromorphic traits were observed in the structure of $K$. pumila leaves, related to: 1$)$ storing water in the ground and epidermal tissues, 2) decreased transpiration (the closing of stomata during heat), 3) avoiding excess insolation of the mesophyll and overheating of the leaf (striated cuticula, anthocyan pigments, tannin storage). The last two groups of xeromorphic traits also include thickening of the outer walls of cuticular cells, a thick-layered cuticula, and the presence of epicuticular wax and calcium carbonate deposits. Microchannels which enhance transpiration efficiency in developing $K$. pumila leaves were found in the vicinity of anticlinal walls in the outer walls of epidermal cells. Calcium deposits produced on the leaf surfaces protect them in extreme conditions. Adaptive traits in the structure of K. pumila leaves are conservative and they confirm the relations between this taxon and the conditions in their native land.

Key words: Kalanchoë pumila, leaf, morphology, anatomy, ultrastructure, xeromorphic adaptation

\section{INTRODUCTION}

Kalanchoё pumila Bak. is a well-known Madagascar (B o i t e a u and A 11 org e - B o i t e a u, 1995; $\mathrm{R}$ a uh, 1995) plant famous for its attractive flowers and leaves (Nikitina, 1994; Czernećkyj and
Weryszko-Chmi e lewska，2003; Descoing s, 2003).

Kalanchoë pumila is one of the two species of the Alpestres Boit. et Mann. group belonging to the Eukalanchoë Boit. et Mann. section, a Kalanchoë Adans. genus of the family Crassulaceae DC. (B o i t e a u and A 11 org e- B o i t e a u, 1995). It is a $30 \mathrm{~cm}$ high shrublet (F ri ed m a n n, 1975) with small, fleshy leaves covered with powdery deposit (Telenkova, 1991). In nature, this succulent is found in the central part of the Madagascar mountains at the altitude of approximately $2000 \mathrm{~m}$ a.s.1., where the climate is wet with a dry and hot 3-6 month long period during the year ( $\mathrm{R} \mathrm{a} \mathrm{u} \mathrm{h}$, 1995). It grows on rocky soils and is rarely epiphytic (D e s c o ing s, 2003).

Since $K$. pumila occurs in extreme conditions in nature, the micromorphology, anatomy and ultrastructure of its leaves have been studied in the ecological aspect.

\section{MATERIALS AND METHODS}

The study material - typical Kalanchoë pumila leaves - was obtained from the collection of greenhouse plants at the Botanical Garden of Maria CurieSkłodowska University, Lublin. The leaf structure was studied with the use of stereoscopic microscopy (SM), light microscopy (LM), scanning electron microscopy (SEM) and transmission electron microscopy (TEM).

The Olympus SZX 12 stereoscopic microscope was used for observation of calcium carbonate deposits and anthocyan pigmentation of the epidermis in freshly sampled leaves. The micromorphological analysis of the fixed leaf material was conducted with the use of the BS 300 Tesla scanning electron microscope. The following parameters were assessed: the morphology and 
position of stomata, the shape of anticlinal walls and the surface of outer epidermis cell walls, the presence and shape of wax structures, and the surface sculpture of the epidermal cuticle.

The study on the anatomy of the leaves was conducted using the Nikon SE light microscopy. The investigations concerned semi-permanent preparations of cross sections and paradermal preparations of fresh and fixed materials. The position and length of stomatal cells, the height of epidermal cells and the thickness of their outer walls, the density of epidermal cells and stomata, the volume of mesophyll cells, and the location of pigment cells were analysed.

Ultrustructural examinations were carried out on the cells of epidermal, parenchymal and secretory tissues (tannin cells) in the leaf lamina. We observed the structure of epidermal and mesophyll cell walls, the ultrastructure of stomatal cells, the structure of nuclei and chloroplasts of the epidermal and mesophyll cells.

LM. For anatomical study, we made glycerine semi-permanent preparations of hand-made cross-sections of the leaf and of paradermal sections of the epidermis.

The material for half-thin preparations was fixed in $2.5 \%$ glutaraldehyde with $2 \%$ paraformaldehyde in $0.1 \mathrm{M}$ cacodylate buffer, $\mathrm{pH} 7.4$ and kept at room temperature for $2 \mathrm{~h}$ and next at $4^{\circ} \mathrm{C}$ for $12 \mathrm{~h}$. The sections were subsequently treated with $1 \%$ osmium tetroxide. After dehydration in ethanol and acetate series, the material was embedded in Spurr Low Viscosity resin. $0.75-1 \mu \mathrm{m}$ thick specimens were cut with a Reichert Ultracut S microtome and stained with $1 \%$ methylene blue and $1 \%$ azure II in 1\% water solution of sodium tetraborate. The sections were fixed in Eukitt synthetic resin.

SEM. Leaf fragments were fixed in $2 \%$ glutaraldehyde with $2.5 \%$ paraformaldehyde in $0.075 \mathrm{M}$ phosphate buffer of $\mathrm{pH} 6.8$ at $4^{\circ} \mathrm{C}$ for $12 \mathrm{~h}$. Next, they were washed twice in the buffer for 15 minutes each and in re-distilled water within the same time. Subsequently, the samples were dehydrated in increasing acetate series $(30,50,70,90$ and $100 \%)$, for 30 minutes in each series. After dehydration, the material was critical point-dried in liquid $\mathrm{CO}_{2}$. The preparations were gold-coated with the use of a CS 100 Sputter Coater and observed in a microscope (SEM).

TEM. Leaf sections were fixed in $2.5 \%$ glutaraldehyde with $2 \%$ paraformaldehyde in $0.1 \mathrm{M}$ cacodylate buffer, $\mathrm{pH} 7.4$ at room temperature for $2 \mathrm{~h}$. and then for another $12 \mathrm{~h}$ at temperature $4^{\circ} \mathrm{C}$. The fixed sections were washed in the buffer alone for $24 \mathrm{~h}$ at temperature $4{ }^{\circ} \mathrm{C}$ and treated with $1 \% \mathrm{OsO}_{4}$. Next, they were transferred into re-distilled water and stained with $0.5 \%$ water solution of uranyl acetate. The material was dehydrated in ethanol series and in increasing concentrations of propylene oxide in alcohol and in pure propylene oxide. After dehydration the specimens were embedded in Spurr Low Viscosity wax for $12 \mathrm{~h}$ at $70^{\circ} \mathrm{C}$. The embedded material was finely cut into ultrathin slices of $60 \mathrm{~nm}$ with the use of a Reichert Ultracut $\mathrm{S}$ ultramicrotome. The sections were treated with $8 \%$ solution of uranyl acetate in $0.5 \%$ acetic acid and lead citrate. The preparations were observed in the transmission electron microscope BS 500 Tesla.

\section{RESULTS}

The leaves of Kalanchoë pumila represent the opposite arrangement on the stem (Fig. 1 A). Their obovate laminas, approximately $2.8 \mathrm{~cm}$ long, $1.7 \mathrm{~cm}$ wide and $2.5 \mathrm{~mm}$ thick, are wedge-shaped at the base and sinuate, sometimes slightly dentate or serrate edge at the tip (Figs $1 \mathrm{~B}, \mathrm{C}$ ). They grow on short (4 mm long), flat stalks which have a furrow on the adaxial surface. The greyish-white colour is produced by a powdery deposit formed by calcium carbonate sediments (Figs $1 \mathrm{~B}, \mathrm{C}, \mathrm{F}, \mathrm{G})$. In the fixed preparations, the deposit was washed out from the leaf surface. After exposition to intensive sunlight, there appears a reddish-brown or purple colour along the leaf margins, due to the presence of anthocyans in the vacuoles of some cells epidermal (Figs 1 D, E) and mesophyll (Fig. 1 F).

The epidermis is composed of a layer of tightly adhering cells (Figs 3 A, C-E), which are slightly higher on the adaxial than on the abaxial surface (Tab. 1). The numbers of epidermal cells on both surfaces of the leaf did not differ notably. On the abaxial surface they are usually more numerous compared to those on the adaxial surface, while the height of epidermal cells displays a reverse pattern (Tab. 1).

When seen from above, the epidermal cells are of a polygonal - isodiametric or slightly oblong shape. Cells surrounding the stomata usually have different shapes and are markedly smaller than the other epidermal cells (Figs 2 A-C). The outlines of the anticlinal walls of the epidermal cells are curved or straight (Figs 2 A, B), unevenly thickened with protuberances or cavities and often with an interrupted cuticle (Figs $2 \mathrm{C}$, F). The surface of the outer walls of the cells is slightly or noticeably convex (Figs 2 A-C). The walls themselves are also thickened due to the thick-film cuticula or the presence of wax. The cuticula is predominantly smooth or slightly undulating, elevated or with striae. There are visible interruptions and some fragments come off of the wall surface (Figs $2 \mathrm{~A}-\mathrm{F}$ ). The usually striated cuticula is found on the subsidiary cells (Figs 2 C, F). Sparse white or grey irregularly shaped and 

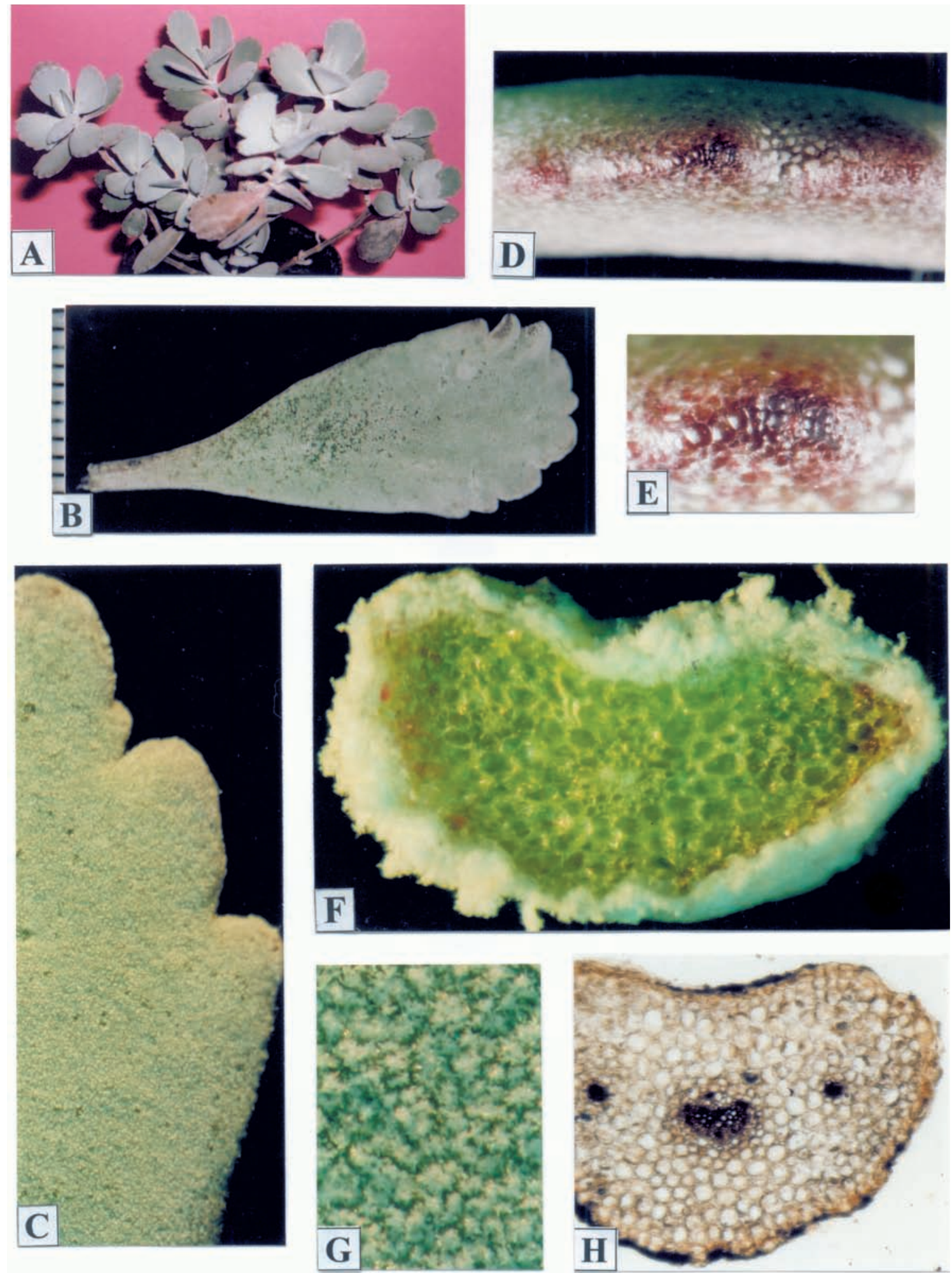

Fig. 1. Morphology and anatomy of K. pumila leaves (SM).

A. Habit of K. pumila $(\times 0.35)$; B. Petiole leaf covered with a powdery deposit; C. Fragment of lamina tip with a dentate margin $(\times 8)$; D, E. Fragment of dentate edge with a visible layer of epidermal cells tinged with anthocyans $(\mathrm{D}-\times 10$; $\mathrm{E}-\times 25) ; \mathbf{F}$. Cross section of the petiole; visible deposits of calcium carbonate on the leaf surface. Some mesophyll cells contain anthocyans $(\times 40)$; G. Lamina surface thickly covered with a powdery deposit (calcium carbonate deposit $)(\times 50)$; H. Fragment of cross section of leaf petiole; mesophyll cells with thickened walls $(\times 30)$. 

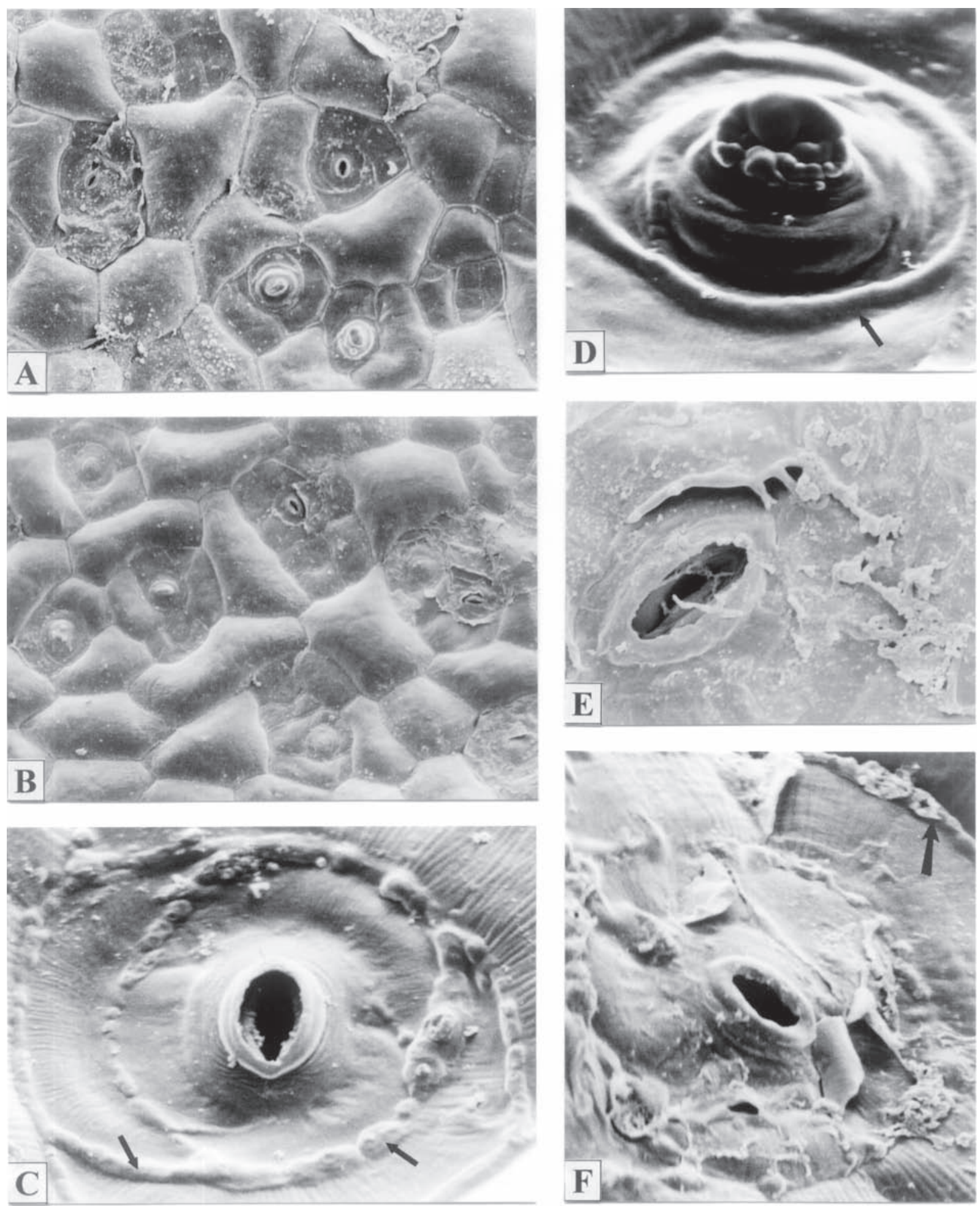

Fig. 2. Micromorphology of $K$. pumila leaf surface (SEM).

A, B. Fragment of upper (A) and lower (B) lamina surface with visible stomata in various developmental stages, and epidermal cells with bulging outer walls $(\times 150)$; C-F. Anisocytic stomata with opened $(C, F)$ or closed $(E)$ pore stomata, with an unknown substance at the opening (D); epidermal cells with visible cuticular striae $(\mathrm{C}, \mathrm{F})$ and thickened anticlinal walls (arrows) $(\mathrm{C}, \mathrm{D}, \mathrm{F})(\mathrm{C}, \mathrm{D}, \mathrm{F}-\times 1260 ; \mathrm{E}-\times 1560)$. 

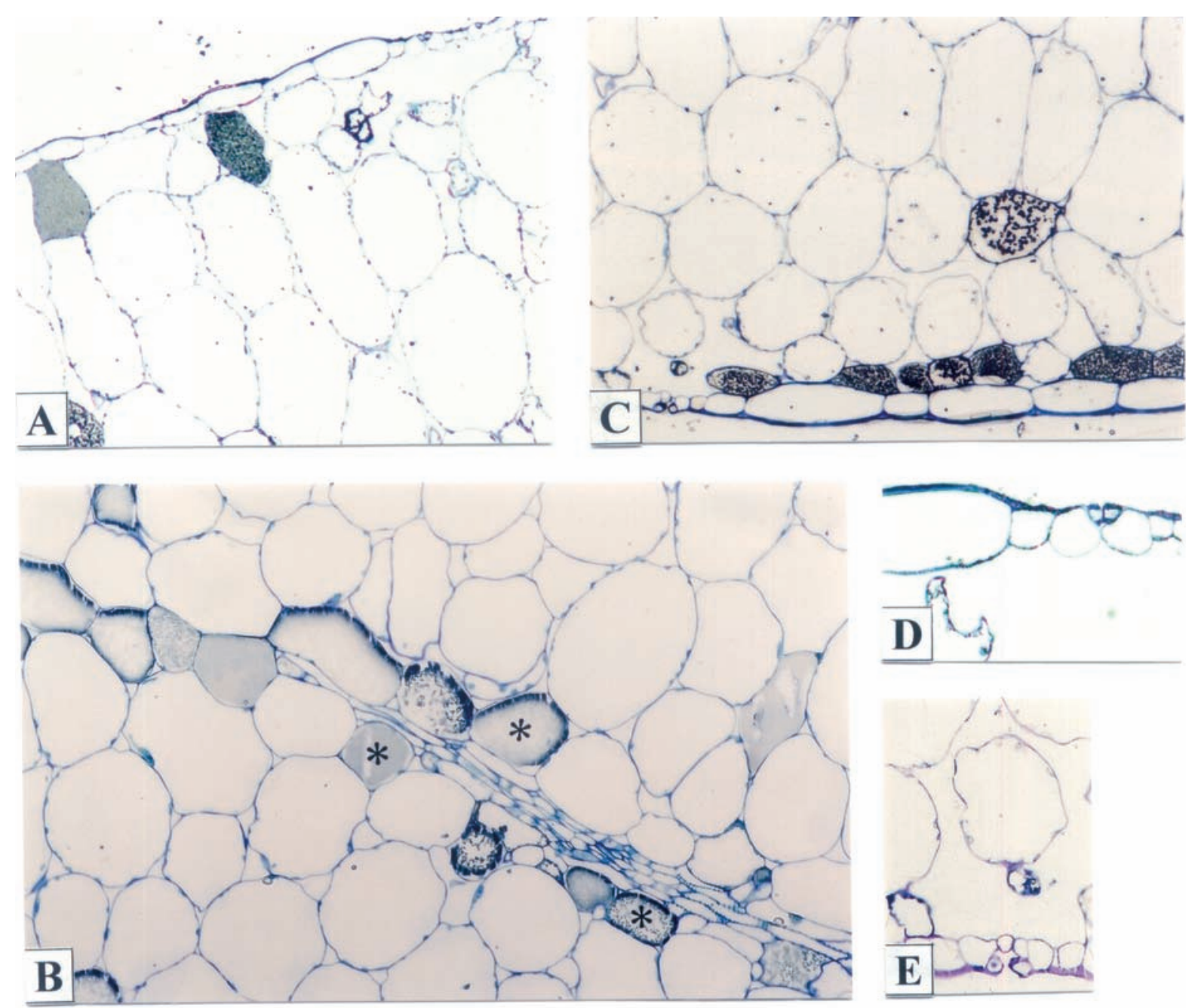

Fig. 3. Anatomical structure of $K$. pumila leaves (LM).

A. The upper part of the lamina with one-layer epidermis and slightly oblong mesophyll cells $(\times 80)$; B. The middle part of the lamina with a fragment of the vascular bundle surrounded by mesophyll cells containing tannins (asterisks) $(\times 110)$; C. The lower part of the lamina with dark-coloured, tannin containing cells under the epiderma ( $\times 110)$; D,E. Upper (D) and lower (E) laminar epidermis with the stomata and thickened outer cell walls $(\mathrm{D}-\times 200 ; \mathrm{E}-\times 130)$. 

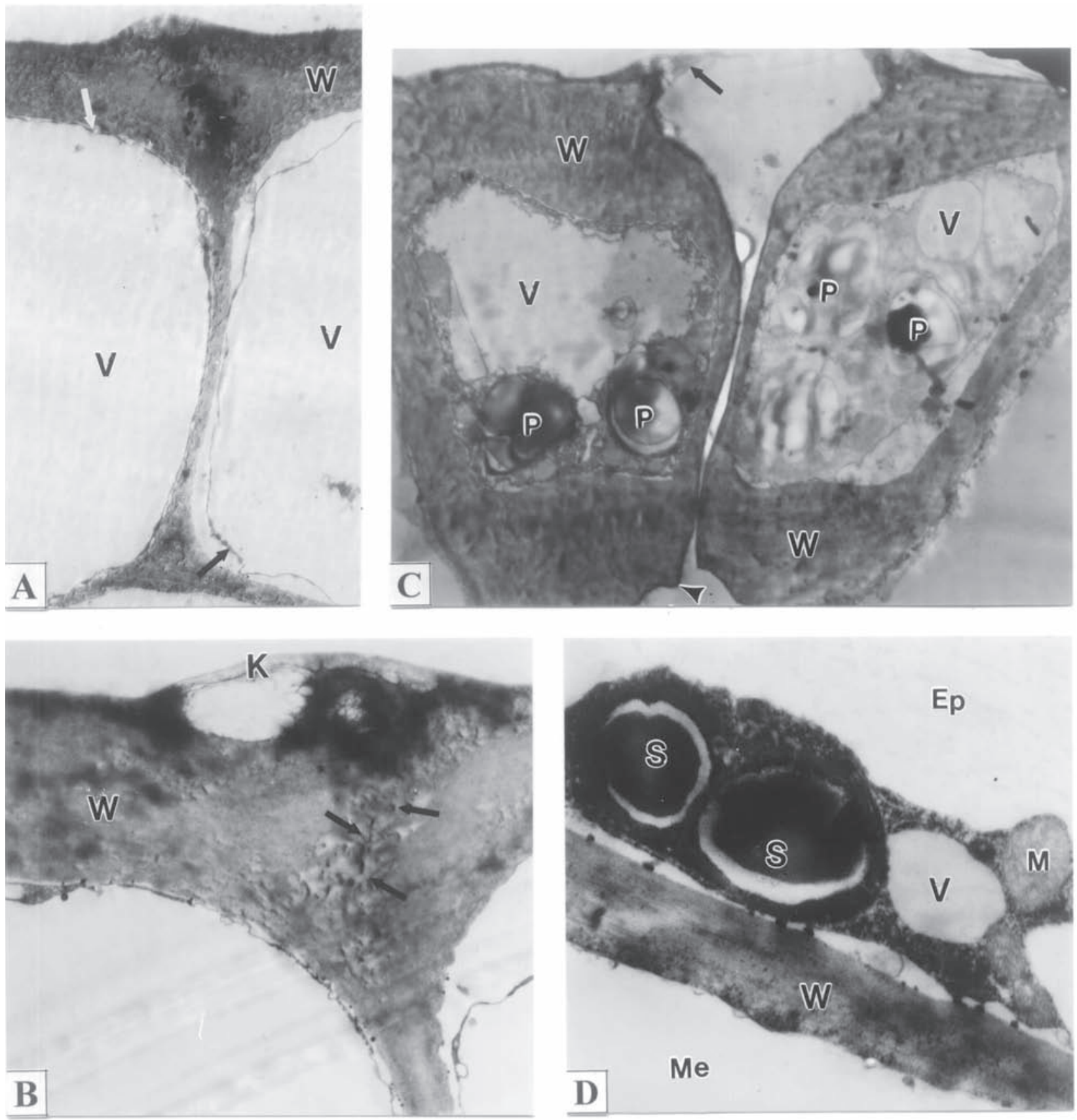

Fig. 4. The ultrastructure of epidermal cells in K. pumila leaves (TEM).

A. Fragments of cells with a thickened outer wall (W), large vacuoles (V) and a thin cytoplasmic layer (arrows) coming off of the wall (right) $(\times 3750)$; B. Fragment of a thickened outer wall $(W)$. A visible microchannel (arrows) and bulging and protruding cuticle $(\mathrm{K})$ in the periclinal wall $(\times 6000)$; C. Stomata cells with thickened walls $(\mathrm{W})$ and outer (arrow) and inner (arrow head) cuticular ledges. Inside the cells visible vacuoles $(\mathrm{V})$ and plastids $(\mathrm{P})$ with starch grains $(\times 2250)$; D. Fragments of epidermal (Ep) and mesophyll (Me) cells with a visible wall (W). In the undulating and slightly protruding epidermal cytoplasm visible vacuoles $(V)$, mitochondria $(M)$ and a plastid with starch grains $(S)(\times 21000)$. 

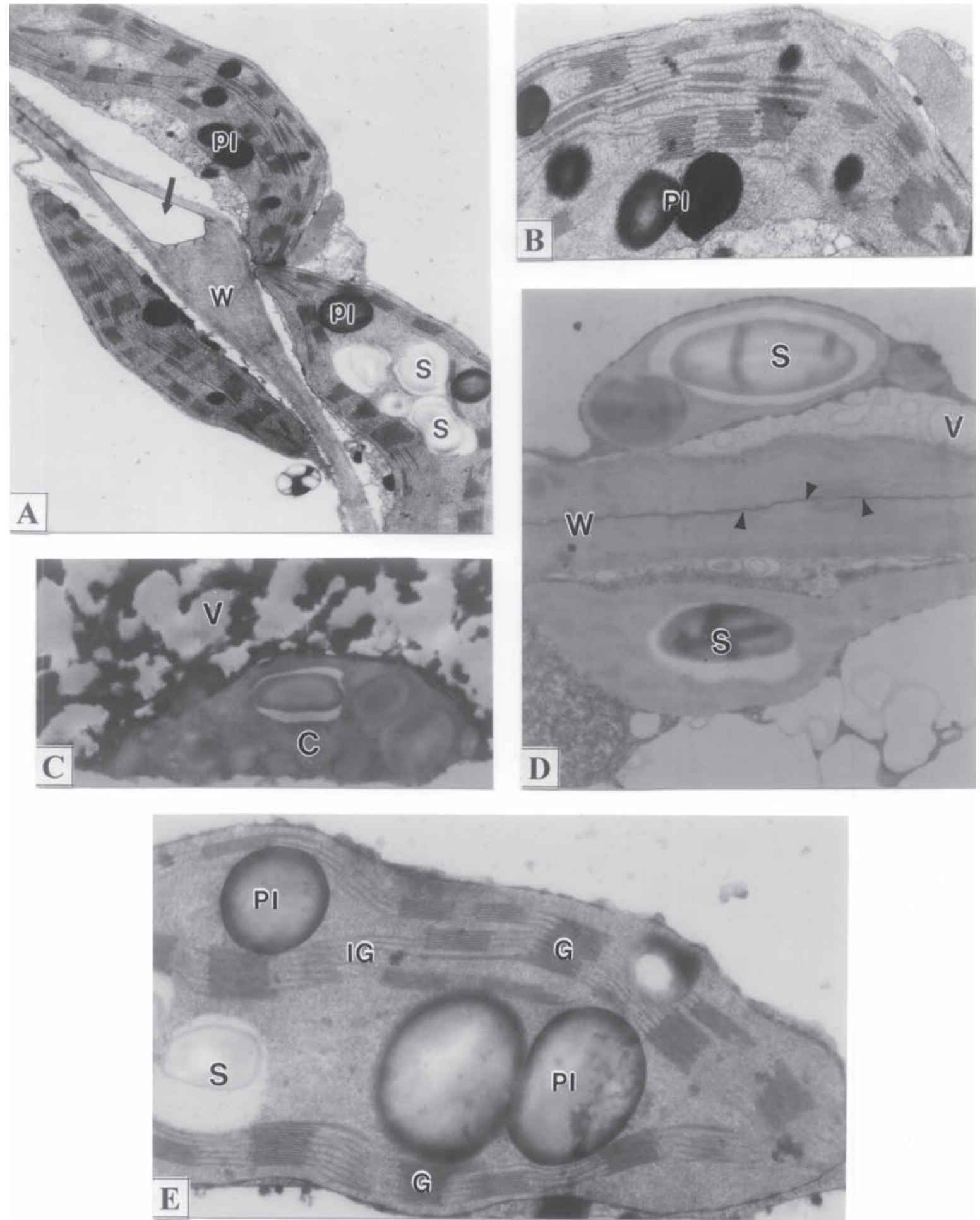

Fig. 5. The ultrastructure of mesophyll cells in K. pumila leaves (TEM).

A. Fragments of two cells with irregularly thickened wall (W) and intercellular space (arrow); in the cytoplasm visible chloroplasts with starch grains $(\mathrm{S})$ and plastoglobules $(\mathrm{Pl})(\times 12000)$; B. A part of a chloroplast with a distinct lamellar system and plastoglobules $(\mathrm{Pl})(\times 27000)$; C. Fragment of a cell with a chloroplast $(\mathrm{C})$ and tannin content in the central vacuole $(\mathrm{V})$ ( $\times 9000)$; D. Fragments of two cells with a visible middle lamella (arrow heads) in the wall (W). Chloroplasts with large starch grains (S). In the cytoplasm visible small vacuoles (V) between the chloroplast and the cell wall ( $\times 12000)$; E. A part of a chloroplast with visible grana $(\mathrm{G})$ and intergrana $(\mathrm{IG})$ thylakoids, a starch grain $(\mathrm{S})$ and plastoglobules $(\mathrm{Pl})(\times 35000)$. 
Table 1

Mean results of measurements of the height of epidermal cells, the length of stomata and their number on a unit of Kalanchoë pumila lamina surface $(\mathrm{n}=30)$.

\begin{tabular}{lcc}
\hline & \multicolumn{2}{c}{ Leaf surface: } \\
\cline { 2 - 3 } Investigated traits & adaxial & abaxial \\
\hline Height of epidermal cells $(\mu \mathrm{m})$ & $47.9 \pm 0.84$ & $45.4 \pm 1.33$ \\
\hline Number of epidermal cells in $1 \mathrm{~mm}^{2}$ area & $183.3 \pm 0.76$ & $190.4 \pm 1.39$ \\
\hline Length of stomatal cells $(\mu \mathrm{m})$ & $33.4 \pm 0.74$ & $33.4 \pm 0.93$ \\
\hline Number of stomata in $1 \mathrm{~mm}^{2}$ area & $22.7 \pm 1.28$ & $25.5 \pm 1.41$ \\
\hline
\end{tabular}

sized wax structures were observed on the surface of the cuticula. They were in the shape of lumps, little rollers (Figs 2 A-D) or plates (Figs 2 E, F) and as a rule they were located in the vicinity of the stomata.

The electron dense epidermal cell walls vary in their thickness. The outer walls are almost 5 times thicker than the others (Fig. 4 A). Microchannels were observed in the outer wall (Fig. 4 B) and the best-developed microchannel was found at the junction of the periclinal and anticlinal walls, where the middle lamella is placed, and it reached the cuticular layer. The cuticle here comes off of the wall and bulges forming follicle-like space (Fig. 4 B). The inner space of the epidermal cells is filled with a large central vacuole (Fig. $4 \mathrm{~A}$ ). In the parietal thin cytoplasmic layer, sometimes coming off of the walls (Figs 4 A, B, D), there are few structures noticeable: irregularly shaped chloroplasts (usually smaller than those in the mesophyll cells) with large starch grains and an abnormal lamellar system, spherically shaped mitochondria as well as endoplasmic reticulum and small vacuoles (Fig. 4 D).

The leaves of $K$. pumila are amphistomatic, because stomata are present in the epidermis of both surfaces and are placed in a multi-directional pattern; they are slightly more numerous in the lower than in the upper side of the laminae (Tab. 1; Figs 2 A, B). The stomata are anisocytic, since they are enclosed by three subsidiary epidermal cells of various volumes, one of them being considerably smaller than the others (Fig. $2 \mathrm{C})$. The length of the stomatal cells is approximately $33 \mu \mathrm{m}$ (Tab. 1). The epidermis contains underdeveloped stomata in various developmental stages. Stomatal pores are either closed (Figs 2 D, E) or opened (Fig. 2 C). The stomata are placed at the level of other cuticular cells (Figs 3 A, C-E). The stomatal cuticle forms thickened outer cuticular ledges, which often overarch the cuticula (Figs 2 C, F; 4 C); the inner ledges are rather poorly formed (Fig. 4 C). Wax structures are frequently observed on the outer cuticular ledges (Figs $2 \mathrm{C}$-E). The periclinal walls of the stomata are 3-10 times thicker than the anticlinal walls (Fig. 4 C). The protoplasts of the above-mentioned cells contain cell nuclei, numerous mitochondria and plastids with enlarged starch grains. One large central vacuole or several smaller ones may be observed inside the cells (Fig. 4 C).

The vascular bundles in K. pumila leaves are collateral and closed. They are in tight contact with the leaf mesophyll through parenchymal bundle sheaths composed of small cells (Fig. $1 \mathrm{H}$ ). Some of the sheath cells or phloem and xylem parenchymal cells may contain tannin substances (Fig. 3 B). Around the vascular bundle, in some places or only near the phloem, there are sclerenchymatic fibres. It should be emphasized that the vascular system of the laminae is more poorly developed, excluding the central bundles.

The chlorenchymatic tissue in K. pumila leaves is not differentiated into the palisade and spongy layers, but it forms small-celled mesophyll under the epidermis and large-celled (water-transporting, CAM-type) mesophyll in the middle part of the leaf. This tissue is built up from tightly adhering parenchymatic cells with well-visible intercellular spaces (Figs $3 \mathrm{~A}-\mathrm{C}$ ). The cells are of a spherical to ellipsoidal shape, which is sometimes irregular due to undulating walls. The cells close to the stomata under the epidermis are loosely distributed, forming visible air-exchange chambers (Figs 3 A, C-E). 
The subepidermal ground tissue usually forms a row of slightly smaller cells (Figs $3 \mathrm{~A}, \mathrm{C}$ ). Their vacuoles often store tannin substances (Figs 3 A, C). Inside the leaves, there is the large-celled mesophyll with large central vacuoles in the cells (Figs $3 \mathrm{~A}-\mathrm{C}$ ), which are responsible not only for photosynthesis but also for storing water in the leaves. Here, the cell volume is 2-6 times bigger than that in the small-celled mesophyll. The mean maximum and minimum diameters of the large-celled chlorenchyma cells in the cross section reached 272.1 ( \pm $35.2)$ and $177.0( \pm 30.4) \mu \mathrm{m}$, respectively.

The chlorenchymatic tissue cells observed in the TEM are characterized by strong vacuolization. As a rule, they contain a big central vacuole, which sometimes stores tannins (Fig. 5 C). The cytoplasm is placed in thin layers in the wall regions of the cells. Sometimes, the plasmolemma is slightly plicate and comes off of the cell wall, thus forming apparent periplasmic spaces (Fig. 5 A).

In the electron dense cytoplasm of the mesophyll cells, there are visible large cell nuclei, numerous pleomorphic variously shaped chloroplasts (Fig. 5 A), mitochondria and other structures. Irregularly shaped chloroplasts occur in the cell protoplasts of the small- and large-celled mesophyll and of the bundle sheaths. They are markedly smaller in the bundle sheath cells than in the other chlorenchyma cells. The oblong plastids contain a rich lamellar system with a regular distribution of grana and intergrana thylakoids; they also contain single or numerous plastoglobules in the electron dense stroma (Figs $5 \mathrm{~A}, \mathrm{~B}$ ). Other plastids in the mesophyll cells are characterized by the presence of various-sized starch grains (1-5) surrounded by a light zone. The occurrence of large starch grains (Figs 5 A, D) or osmophilic structures (Figs $5 \mathrm{~A}, \mathrm{~B}, \mathrm{E})$ in the chloroplasts results in an abnormal lamellar system in their structure and provides their irregular shape.

The electron dense mesophyll cell walls are unevenly thickened, especially in the neighbourhood of the intercellular spaces (Fig. 5 A). In the walls, there are well-visible middle lamellae (Figs 5 A, D) as well as frequent plasmodesmata.

The tannin-bearing mesophyll cells are located in the vicinity of the vascular elements (Fig. 3 B) and under the epidermis, thus forming a whole or an interrupted layer (Figs $3 \mathrm{~A}, \mathrm{C}$ ). Tannin cells are quite commonly scattered, individually as idioblasts (Fig 3 C), or in groups, in the mesophyll tissue (Fig. 3 B). Their chloroplasts are very small and they contain spherical osmophilic structures or single starch grains (Fig. 5 C). They are several times smaller than the chloroplasts of typical chlorenchymatic tissue cells in the leaf. The centrally placed vacuoles are electron dense and filled with dark, floccular content (Fig. 5 C).

\section{DISCUSSION}

The small-sized, succulent Kalanchoë pumila leaves that store water in the mesophyll cells have numerous traits in their structure that help the plant adapt to xerothermic conditions. Among the histological plant systems, it is the epidermal tissue that is the most active in adaptation. It is well-known that the epidermis, being the protective-regulatory system, is fairly complex in its structure; it provides plant organisms with ecological flexibility, and its stable structure characteristics are important for taxonomy (M i r o s l a v o v, 1974; Juniper and J e f free, 1983; He j n ow i c z, 2002). The structure of the K. pumila epidermal tissue is taxonomically specific, but it also shares traits typical for plants from the Kalanchoë genus. The leaves are amphistomatic, covered with a single-layer epidermis with thickened outer cell walls, a thick layer of cuticle, often with a wax deposit, and with anisocytic stomata; this was observed by other researchers, too, in individual species of this genus ( $\mathrm{Sh}$ arma and $\mathrm{Dunn}$, 1968; Inamdar and Pate 1, 1970 ; Czernecki, 2006$)$.

The epidermis of $K$. pumila leaves displays numerous xeromorphic traits in its structure. The thick layer of cuticula fulfils various protective functions, since it participates in limiting transpiration (M i r oslavov, 1974; Juniper and Jeffree, 1983; Kersti en s, 1996; S c hreiber et al. 2006) it also prevents pathogen and entomofauna invasion and is a barrier against toxic environmental pollution ( $\mathrm{M} \mathrm{i} \mathrm{-}$ roslavov, 1974; Juniper and Jeffree, 1983). The cuticle is also known to protect the plant from the unfavourable effect of ultraviolet radiation ( $\mathrm{M} \mathrm{i}$ roslavov, 1974; Semerdjieva et al. 2003). Studies have demonstrated that the epidermis usually stops ultraviolet light inefficiently. Only in xerophytes does the cuticula contain light-yellow pigment (a flavonoid derivative) which protects against intensive UV rays (M i r o s l a v o v, 1974).

Juniper and Jeffree (1983) claim that the cuticle has neither pores nor channels and the cuticular transpiration takes place by diffusion. However, Franke (1969) proves that the cuticle is most permeable in the place where ectodesmata are located in the outer epidermal walls, which are most numerous in the anticlinal walls of the cuticle and stomata. Other researchers (Y a m a d a et al. 1966) observed that the cuticle is most permeable to various substances in the anticlinal wall zones of epidermal cells. Yet, while analyzing the work of his predecessors, Miros lav o v (1974) demonstrated the presence of sub-microscopic apertures in some regions of the cuticular cover. The cuticle is most permeable to water over the anticlinal walls of cuticular and stomatal cells. Cuticular 
transpiration is very intense here and the wax deposits are usually smaller. The present work demonstrates that the cuticle over the anticlinal walls of epidermal cells in $K$. pumila was bulging and it came off, thus forming a follicle-like space. The cuticle on the leaf surface along the anticlinal walls of the epidermis was of a varied thickness, it formed bulges or cavities, and it was often ruptured.

The cuticle surface of the outer epidermal walls in K. pumila is usually smooth or delicately undulated; it can also have distinct striae predominant on the subsidiary cells. J u n i p e r and J e ffre e (1983) emphasize that the presence of various types of appendages and cuticular sculptures on the surface of flower petals produces stronger sunlight dispersion, which may also apply to the specific formation of the leaf surface. A smooth surface of the cuticle in epidermal cells with flat outer walls releases water more quickly than an undulating surface (M i r o s l a v o v, 1974).

Epicuticular wax is the first barrier isolating the plant from the surrounding environment (M i r o s l a vov, 1974; J uniper and Jeffree, 1983) and it is a characteristic feature of most taxa of the Crassulaceae family (F e hre n b a ch, 1989). The latter author distinguished a few types of epicuticular wax: rodshaped, ribbon-shaped, scale-shaped and thread-like wax on the surface of the overground organs in some representatives of this family. In the present study, however, we observed sparse granular, rod-shaped and plate-like wax structures on the K. pumila leaf surface which either covered or blocked the stomatal apertures. According to J effree et al. (1971), such stomatal wax corks let $\mathrm{CO}_{2}$ through easily, but they decrease transpiration intensity. Light is an important factor for wax formation on the plant surface (M i r o s l a v o v, 1974; Juniper and J effree, 1983). In succulents and other xerophytes, the presence of wax is an essential adaptive trait as the wax layer effectively alleviates the adverse effect of light and temperature and has a protective role during osmotic stresses, physical damage and contamination ( J u n i per and J e f free, 1983; Fehrenbach, 1989; Kerstiens, 1996; Shepherd and Griffith s, 2006).

Besides wax deposits on the leaf cuticle surface in K. pumila, there is also a white-greyish powdery deposit which feels and tastes like chalk. It is, most probably, calcium carbonate water-washable sediment that gets removed while rinsing the plants. They stay on the surface of the leaves in the form of numerous white, small crystals. When washed out or mechanically removed from the surface of mature leaves, they reappear, but less intensively. T e l e $\mathrm{n} \mathrm{k} \mathrm{o} \mathrm{v}$ a (1991) reports that the surface of $K$. pumila leaves and young shoots is covered with a white powdery deposit. According to B e r g e r (1930), the surface of the overground vegetative organs and sepals in $K$. pumila is covered with glandular trichomes. However, in the present research, no types of trichomes were observed on the leaf surface. B e r g e r (1930) might, therefore, have regarded clusters of calcium carbonate crystals as glandular trichomes. Such clusters look like white, tightly adhering lumps when observed under low magnification. In their papers, other systematicians ( $\mathrm{H} \mathrm{a} \mathrm{met}$ and Marnier-Lapostolle, 1964; Boiteau and A 11 orge-B o ite a u, 1995; Des c o ing s, 2003) described that powdery deposit in K. pumila as wax.

Some authors (E1ler and Willi, 1977), based on the reports of predecessors ( $\mathrm{Hamet}$ and Marnier-Lapostolle, 1964), also assumed the powdery deposit on $K$. pumila leaves to be wax structures. The above-mentioned authors observed that absorption of global radiation increases up to $55 \%$ after the cover has been removed from young $K$. pumila leaves. An intact cover on $K$. pumila leaves markedly increases the light reflection coefficient and decreases the extent of near-red radiation (K e r s t i e n s, 1996). Thus, one can presume that the calcium carbonate deposits on the $K$. pumila leaf surface play an adaptive role for the plant.

It is highly probable that $K$. pumila is a calciphyte, i.e., a calciphilic plant. S o k o lov (1990) reports that the flora of the semi-arid south-west of Madagascar contains calciphytes occurring on the calcifierous plateaux. Among them, there are plants belonging to the Kalanchoë genus. K. pumila, however, is not found in the vegetation of this region, but it is common on rocks in the central part, where the climate is wet with a dry and hot period during the year ( $\mathrm{R} \mathrm{a} \mathrm{u} \mathrm{h}$, 1995). Calciphilic plants are mainly xerophytes; still, many of them grow on soils which may differ in humidity but always contain limestone (A l e chin, 1944). Calcification and salinization are characteristic for the soils from dry climates (K o r n a ś and M ed w e c k a - K or n a ś , 2002). The bedrock in the mountainous regions in central Madagascar is composed of calcareous and non-calcareous rock ( $\mathrm{S} \mathrm{ok} \mathrm{olov}$, 1990), on which K. pumila plants are found (R a u h, 1995).

Not always can calcium carbonate or salt deposits be observed on the surface of overground organs because this is probably dependent on the concentration of the compounds mentioned above in the water taken up from the substratum (Alechin, 1944). Such deposits on plant surfaces may only appear thanks to specialized secretory structures. $\mathrm{Ca}^{2+}$ rich solution secreted through diverse exogenous secretory tissues react with carbonate ions, thus forming a white calcium carbonate deposit in the sites of secretory structures on 
the surface of organs (H e j n o w i c z, 2002). No exogenous secretory tissues, however, were observed in the K. pumila leaf structure. Mi z u no et al. (2003) report that Thlaspi japonicum plants growing on soils with high $\mathrm{Ni}$ content are capable of releasing excess metal ions from the leaves through stomatal transpiration and gutation. Dense calcium carbonate deposits on the surface of $K$. pumila leaves are presumably formed by stomatal or cuticular transpiration from calcium ions present in the water that evaporates after the reaction with carbonate ions.

The present study (TEM) demonstrated that in the outer walls of the epidermal cells in K. pumila there are microchannels in the vicinity of the anticlinal walls. The cuticle in these regions very often protrudes and is interrupted or unevenly thick, which facilitates permeation of water and other substances ( $\mathrm{Y} \mathrm{a} \mathrm{m} \mathrm{a} \mathrm{d} \mathrm{a}$ et al., 1966; F r a n k e, 1969; M i r o s lavo v, 1974). Jenks et al. (1994) suggest that epicuticular wax may flow out from the microchannels in the epidermal walls. Undoubtedly, the presence of the microchannels enhances water evaporation in developing $K$. pumila leaves during vegetation, while calcium sediments produced on the leaf surface probably protect it from excessive transpiration and sunlight in the dry and hot period.

The volume of leaf epidermal cells displays the relationship between a plant and its habitat. Smallsized cells are typical for plants growing in dry regions (Miroslavov, 1974). The results of the present study have demonstrated that the abaxial epidermis of $K$. pumila leaves is composed of smaller cells than those on the adaxial surface. This is related to the number of epidermal cells in a unit of surface. A comparison of the present results with the data of other researchers shows that the number of epidermal cells on $1 \mathrm{~mm}^{2}$ surface of the K. pumila leaf is 1.7-2 times larger than in K. fedtschenkoi ( $\mathrm{S}$ h a r m a and D u n n, 1968 ) and 7-30 times smaller than the number of epidermal cells in xerophytic and mesophytic tree cells (Vas i liye v, 1969; Hej n ow i c z, 2002). Therefore, compared to sclerophytes and mesophytes, the leaf epidermis in leaf succulents has large cells and additionally fulfils the water storage function. Vas ili ye v (1969) reports that the large-celled water storing epidermis protects the assimilation tissue from sun radiation by partial reflection and absorption thereof. The author also suggests that intense cuticular transpiration in these epidermal cells may alleviate overheating of the organ.

The anticlinal walls of $K$. pumila leaf epidermal cells are straight or flexed. Wa t s on (1942) reports that in plants growing under intensive sunlight exposure the undulation of anticlinal walls is less pro- nounced than in plants from shadowy places. At times, the vacuoles of epidermal and mesophyll cells in the leaf margins may contain anthocyan pigments that provide the leaves with reddish-brown or purple tinge. Anthocyan compounds play an important protective role against ultraviolet radiation, since many of them are capable of absorbing rays in this range ( $\mathrm{S} t \mathrm{e} \mathrm{y} \mathrm{n}$ et al. 2002; L i a k o oulo s et al. 2006).

Chloroplasts were observed in the cytoplasm of K. pumila epidermal cells. In land dicotyledons, there usually occur leucoplasts. With the use of fluorescence tests and silver nitrate reduction, $\mathrm{M} \mathrm{i} \mathrm{k} \mathrm{u} \mathrm{ls} \mathrm{k} \mathrm{a} \mathrm{(1959)}$ observed green plastids in epidermal cells of numerous land plants, among others, in K. tubiflora. The chloroplasts in $K$. pumila epidermal cells were irregularly shaped, smaller than the mesophyll chloroplasts and their lamellar system was abnormal due to the presence of large starch grains. M i r o s l a v o v (1974) reports that the lamellar system in the chloroplasts of typical $K$. daigremontiana epidermal cells is less developed than in the green plastids of mesophyll cells. Freeman (1973) suggests that the differences between epidermal and stomatal chloroplasts may be essential in eliciting the function of xerophyte stomata.

Distribution of stomata related to the level of the epidermis and their density on the leaf surface are important traits characterizing plants from diverse ecological groups. Stomata embedded in the epidermis and placed on both sides of the leaf are typical for xerophytic plants (M i r o s la v o v, 1974; R o t o n d i et al., 2003). In K. pumila, stomata are located on the same level as epidermal cells, but they are not as high as the cells of the epidermal tissue. Above the level of the epidermis, there are outer cuticular ledges, which undoubtedly protect the stomatal cells by dispersing sunlight. The presence of such ledges enables the plant to optimize the ratio between transpiration and $\mathrm{CO}_{2}$ uptake (J un i per and J e f free, 1983).

The lower epidermis in K. pumila leaves produces some more stomata than the upper one, which confirms the results of earlier analogous studies on $\mathrm{Ka}$ lanchoë fedtschenkoi (S h a r m a and D u n n, 1968). There may be 23-26 stomata of an approximate length of $33 \mu \mathrm{m}$ in $1 \mathrm{~mm}^{2}$ of leaf surface. Following S u n berg and Marshall (1986), in leaf succulents, the number of stomata in this unit of surface is smaller than 50 , while in xerophytes or mesophytes the number is 2-10 times bigger. Disregarding the slits formed by cuticular ledges in mature stomata, a majority of the stomata in K. pumila had generally closed apertures. It is typical for Crassulaceae family plants to close the stomata in daylight insolation and transpiration and to open them only at night. This adaptive trait classifies them as CAM ("crassulacean acid metabolism") 
photosynthesis plants (K1uge et al. 1992; Kondo et al. 2001).

The stomatal cells are characterized by thickened, electron dense walls, which is typical for xerophytes (M i r o s l a v o v, 1974). Their periclinal walls are usually several times thicker than the anticlinal walls. Numerous mitochondria and chloroplasts visible in the cytoplasm distinctly differ from these organellae in the epidermal and mesophyll cells. Large starch grains are typical for green plastids of stomatal cells (Freeman, 1973; Miroslavov, 1974), which was also observed in K. pumila.

The vascular system in $K$. pumila leaves is poorly developed, especially in the leaf lamina, which was also observed in plants of the Sedum genus (B e rezkin a, 2006).

The assimilation tissue of the K. pumila leaf is divided into the subepidermal small-celled and largecelled mesophyll in the central part of the leaf. The cells of the large-celled mesophyll are highly vacuolized. Apart from their participation in the photosynthesis process, they store water (water-transporting mesophyll, CAM type). It is widely known that leaf succulents tend to store water in the parenchyma placed deep in the leaf, which leads to enlargement of their vacuoles. The central part of the leaf in succulents of Aloë, Peperomia, Senecio genera and other taxa contains a specialized water-transporting tissue with single chloroplasts ( $\mathrm{K} \mathrm{a} \mathrm{u} \mathrm{1,} \mathrm{1977;} \mathrm{T}$ i m o $\mathrm{n}$ i n and O z e rova, 1993; Chauser-Volfson et al. 2002). However, there is no such tissue in the Kalanchoë genus or other Crassulaceae family taxa (M e t c a $1 \mathrm{fe}$ and $\mathrm{Chalk}, 1957)$.

The differentiated structure of chloroplasts in the assimilation tissue cells in $K$. pumila leaves is an interesting trait. In the cytoplasm of both small- and large-celled mesophyll, there are numerous pleomorphic, variously shaped chloroplasts. In the bundle sheath cells, the chloroplasts were sparse and very small and they had single starch grains in the stroma and poorly visible thylakoids. Similar differentiation of the chloroplast structure was observed by other researches, too (S a rda et al. 1975), and the presence of a big amount of starch in the chloroplasts of the water-transporting mesophyll cells in some Kalanchoë species was reported by K ond o et al. (2001). The anatomical structure of $K$. pumila leaves as well as the ultrastructure of their assimilation tissue cells indicate that this species belongs to type $\mathrm{C}_{3}$ photosynthesis together with other taxa of the Kalanchoë genus (Sarda et al. 1975; K o n d o et al. 2001). CAM photosynthesis, however, as an adaptive trait, is induced by external factors (B rulfert et al. 1995).

Ground tissue cells containing tannins are well described for the plants of the Crassulaceae fam- ily (Metcalfe and Chalk, 1957). In K. pumila leaves they are usually stored under the epidermis, in the vacuoles of the small-celled mesophyll and bundle sheaths, thus forming whole or interrupted layers. Such tannin-bearing cells were either scattered as single idoblasts or they were clustered in the large-celled mesophyll. Similar distribution in $K$. daigremontiana leaves was reported by B a $1 \mathrm{~s} \mathrm{a} \mathrm{mo} \mathrm{and} \mathrm{U} \mathrm{ribe} \mathrm{(1988).} \mathrm{The}$ tannin-bearing K. pumila cells have small chloroplasts with single starch grains and osmophilic structures. Their central vacuoles are electron dense with dark, floccular content, which was analogous in other plants (B a č i ć et al. 2004). The content of tannin substances in plant organs is an important adaptive trait, as they play a protective role against UV radiation by absorbing rays that are harmful to plant organs. Moreover, they protect plants from pathogen factors and damage caused by the entomofauna (K o p c e w ic z and Lew ak, 2005).

\section{Acknowledgments}

We wish to thank Mr Janusz Matusiewicz, MSc., the previous Head of the Microscopy Laboratory of the University of Life Sciences, Lublin, for assistance in preparing the material for the transmission electron microscopy. We also thank Mr Marek Wróbel, MEng., for his help in elaborating the samples and providing access to the scanning electron microscopy.

\section{REFERENCES}

Alechin V. V., 1944. Geografiâ rastenij / Plant Geography. Sovetskaâ nauka, Moskva.

Bačić T., Ljubešc N., Užarević Z., Grgić L., Roša J., 2004. TEM investigation of tannins and chloroplast structure in needles of damaged silver fir trees (Abies alba Mill.). Acta Biol. Cracov. ser. Bot. 46: 145-149.

Balsamo R., Uribe E., 1988. Leaf anatomy and ultrastructure of the Crassulacean-acid-metabolism plant Kalanchoë daigremontiana. Planta, 173 (2): 183-189.

Berezkina V. I., 2006. Morfologo-anatomična charakterystyka vegetatyvnych organiv vydiv sekciï Telephium S.F. Gray rodu Sedum L. / Morphologo-anatomical characteristic of vegetative organs of the genus Sedum L. species of the section Telephium S. F. Gray. Visnyk Kyïvc'kogo Nacion. Univer. im. T. Ševčenka, ser. Introdukciâ ta Zberežennâ Roslynnogo Riznomanittâ, 10: 4-6.

Berger A., 1930. Crassulaceae. [In:] A. Engler und K. Prantl (eds), Die Natürlichen Planzenfamilien, Bd 18a, 352483. Verlag von Wilhelm Engelmann, Leipzig.

Boiteau P., Allorge-Boiteau L., 1995. Kalanchoë de Madagascar. Systématique, écophysiologie et phytochemie. Karthala, Paris. 
Brulfert J., Ravelomanana D., Kluge M., 1995. Écophysiologie des Kalanchoë. Le Métabolisme Acid des Crassulacées (CAM): une voie photosynthétique adaptative. [In:] P. Boiteau et L. Allorge-Boiteau (eds), $\mathrm{Ka}$ lanchoë de Madagascar. Systématique, écophysiologie et phytochemie, 207-218. Karthala, Paris.

Chauser-Volfson E., Shen Z., Hu Z., Gutterman Y., 2002. Anatomical structure and distribution of secondary metabolites as a peripheral defence strategy in Aloë hereroensis leaves. Bot. J. Linn. Soc. 138: 107-116.

Czernecki M. (Chernetsky y M.), 2006. Mikromorfologia epidermy liści wybranych gatunków Kalanchoë Adans. / Micromorphology of leaf's epidermis of some species of Kalanchoë Adans. Rocznik EKPiUU (Lublin), 3: 371380.

Czernećkyj M. (Chernetskyy M.), WeryszkoChmielewska E., 2003. Atrakcyjność liści kilku gatunków Kalanchoë Adans. / The attractiveness of leaves in several Kalanchoë Adans. species. Folia Hort. supl. 2: 49-52.

Descoings B., 2003. Kalanchoë. [In:] U. Eggli (ed.), Illustrated Handbook of Succulent Plants: Crassulaceae, 143181. Springer-Verlag, Berlin-Heidelberg-New York.

Eller B. M., Willi P., 1977. Die Bedeutung der Wachsausblühungen auf Blätter von Kalanchoë pumila Baker für die Absorption der Globalstrahlung. Flora (Jena), 166: 461-474.

Fehrenbach S., 1989. Die Wachse auf den Oberflächen der Crassulaceen. Kakteen und andere Sukkulenten, 40 (7): 166-168.

Franke W., 1969. Ectodesmata in relation to binding sites for inorganic ions and urea on isolated cuticular membrane surfaces. Amer. J. Bot. 56: 432-435.

Freeman T. P., 1973. Developmental anatomy of epidermal and mezophyll chloroplasts in Opuntia basilaris leaves. Amer. J. Bot. 60 (1): 86-91.

Friedmann F., 1975. Formes de croissance et multiplication végétative des Kalanchoë malgaches. Candolla, 30 (1): 177-188.

Hamet R., Marnier-Lapostolle J., 1964. Le genre Kalanchoё au jardin botanique "Les Cèdres". Arch. Mus. Natn. Hist. Nat. 8: 1-107.

Hejnowicz Z., 2002. Anatomia i histogeneza roślin naczyniowych. Organy wegetatywne / Anatomy and histogenesis of vascular plants. Vegetative organs. PWN, Warszawa.

Inamdar J. A., Patel R. C., 1970. Structure and development of stomata in vegetative and floral organs of three species of Kalanchoё. Ann. Bot. 34: 965-974.

Jeffree C. E., Johnson R. P. C., Jarvis P. G., 1971. Epicuticular wax in the stomatal antechamber of sitka spruce and its effects on the diffusion of water vapour and carbon dioxide. Planta, 98 (1): 1-10.

Jenks M. A., Rich P. J., Ashworth E. N., 1994. Involvement of cork cells in the secretion of epicuticular wax filaments on Sorghum bicolor (L.) Moench. Internat. J. Plant Sci. 155: 506-518.

Juniper B. E., Jeffree C. E., 1983. Plant surfaces. Edward Arnold, London.
Kaul R. B., 1977. The role of the multiple epidermis in foliar succulence of Peperomia (Piperaceae). Bot. Gaz. 138 (2): 213-218.

Kerstiens G. (ed.), 1996. Plant Cuticles - an Integrated Functional Approach. BIOS Scientific Publishers, Oxford.

Kluge M., Razanoelisoa B., Ravelomanana D., Bruleert J., 1992. In situ studies of crassulacean acid metabolism in Kalanchoë beharensis Drake Del Castillo, a plant of the semi-arid southern region of Madagascar. New Phytol. 120: 323-334.

Kondo A., Nose A., Yuasa H., Ueno O., 2001. Coordinated accumulation of the chloroplastic and cytosolic pyruvate, Pi dikinases with enhanced expression of CAM in Kalanchoë blossfeldiana. Physiol. Plant. 111: 116-122.

Kopcewicz J., Lewak S. (eds), 2005. Fizjologia roślin PWN, Warszawa.

Kornaś J., Medwecka-Kornaś A., 2002. Geografia roślin PAN, Warszawa.

Liakopoulos G., Nikolopoulos D., Klouvatou A., Vekkos K.-A., Maneta G., Karabourniotis G., 2006. The photoprotective role of epidermal anthocyanins and surface pubescence in young leaves of grapevine (Vitis vinifera). Ann. Bot. 98: 257-265.

Metcalfe C. R., Chalk L., 1957. Anatomy of the dicotyledons, Vol. 2. Clarendon Press, Oxford.

Mikulska E., 1959. Chloroplasty w skórce liści roślin dwuliściennych / Sur l'existence des chloroplastes dans l'épiderme des feuilles des Dicotylédones. Acta Soc. Bot. Polon. 28 (1): 143-173.

Miroslavov E. A., 1974. Struktura i funkciâ èpidermisa lista pokrytosemennych rastenij / Structure and function of leaf epidermis of angiosperms plants. Nauka, Leningrad.

Mizuno N., Nosaka S., Mizuno T., Horie K., Obata H., 2003. Distribution of $\mathrm{Ni}$ and $\mathrm{Zn}$ in the leaves of Thlaspi japonicum growing on ultramafic soil. Soil Sci. Plant Nutr. 49 (1): 93-97.

Nikitina V. V., 1994. Biology of the Kalanchoë Adans. genus species in the covered soil environment and their use in future. Dissertation for competetion of biological sciences candidate's degree in the speciality botany. Gryshko M.M. Central Botanical Garden of NAS of the Ukraine, Kyiv.

Rauh W., 1995. Succulent and xerophytic plants of Madagascar, Vol. 1 and 2, Strawberry Press., Mill Valley (US: CA).

Rotondi A., Rossi F., Asunis C., Cesaraccio C., 2003. Leaf xeromorphic adaptations of some plants of a coastal Mediterranean macchia ekosystem. J. Mediterr. Ecol. 4 (3-4): 25-35.

Sarda G., Prioul J. L., Moyse A., 1975. Structure du limbe et accumulation d'amidon dans les chloroplastes des feuilles d'une Crassulacée, Bryophyllum daigremontianum Berger. Physiol. Vég. 13: 563-577.

Schreiber L., Elshatshat S., Koch K., Lin J., Santrucek J., 2006. AgCl precipitates in isolated cuticular membranes reduce rates of cuticular transpiration. Planta, 223: 283-290. 
Semerdjieva S. I., Phoenix G. K., Hares D., GwynnJones D., Callaghan T. V., Sheffield E., 2003. Surface morphology, leaf and cuticle thickness of four dwarf shrubs from a sub-Arctic heath following longterm exposure to enhanced levels of UV-B. Physiol. Plant. 117: 289-294.

Shepherd T., Griffiths D. W., 2006. The effects of stress on plant cuticular waxes. New Phytol. 171: 469-499.

Sharma G. K, Dunn D. B., 1968. Effect of environment on the cuticular features in Kalanchoë fedtschenkoi. Bull. Torrey Bot. Club, 95 (5): 464-473.

Sokolov V. E. (ed.), 1990. Madagaskar, (trans. from eng. on rus. M.A. Aršinova - A. Jolly, P. Oberlé and R. Albignac (eds), Madagascar). Progress, Moskva.

Steyn W. J., Wand S. J. E., Holcroft D. M., Jacobs G., 2002. Anthocyanins in vegetative tissues: a proposed unified function in photoprotection. New Phytol. 155: 349-361.

Sunberg W., Marshall D., 1986. A comparison of stomatal distribution and length in succulenten and nonsucculent desert plants. Phytomorphology, 36 (1-2): 53-66.

Telenkova T. V., 1991. Opredelitel vidov semejstva Crassulaceae DC / Classification key for Crassulaceae DC. family plants. [In:] A. Golovkin (ed.), Oranžerejnye rasteniâ / Greenhouse plants, 140-192. Nauka, Moskva.

Timonin A. K., Ozerova L. V., 1993. Stroenie, proischoždenie i èvoluciâ val'kovatych list'ev sekcii Rowleyani C. Jeffrey roda Senecio L. (Asteraceae) / Structure, origin and evolution of the terete leaves in Rowleyani C. Jeffrey section of Senecio L. genus (Asteraceae). Izvestiâ AN Rossii, ser. Biol. 3: 393-401.

Vasiliyev B. R., 1969. K anatomii lista nekotorych Combretaceae zapadnoafrikanskoj savanny / A contribution to the foliar anatomy of some Combretaceae of the West-African savanna. Bot. Zhurnal (St.-Petersburg), 54 (7): 1092-1099.

Wats on R. W., 1942. The effects of cuticular hardening on the form of epidermal cells. New Phytol. 41 (4): 223-229.

Yamada Y., Rasmussen H.P., Bukovac M. J., Wittwer S. H., 1966. Binding sites for inorganic ions and urea on isolated cuticular membrane surfaces. Amer. J. Bot. 53 (2): 170-172.

\section{Struktura liści Kalanchoë pumila Bak. (Crassulaceae DC.)}

\section{Streszczenie}

Przy zastosowaniu mikroskopii stereoskopowej, świetlnej oraz skaningowej i transmisyjnej elektronowej badano strukturę liści Kalanchoë pumila Bak. Stwierdzono, że tkanka chlorenchymatyczna w liściach jest podzielona na mezofil drobnokomórkowy subepidermalny oraz mezofil wielkokomórkowy (wodonośny, typu CAM) położony w środkowej części liścia. Budowa mezofilu i ultrastruktura jego komórek wskazuje na $\mathrm{C}_{3}$ typ fotosyntezy u tego taksonu, a fotosynteza typu CAM, jako syndrom przystosowawczy, indukowana jest czynnikami zewnętrznymi.

W strukturze liści $K$. pumila zaobserwowano trzy grupy cech kseromorficznych związanych $\mathrm{z:}$ 1) magazynowaniem wody w tkance miękiszowej i epidermalnej, 2) obniżeniem transpiracji (zamknięcie aparatów szparkowych w czasie upału), 3) ze zmniejszeniem nasłonecznienia mezofilu i przegrzewania liścia (prążkowana kutykula, występowanie barwników antocyjanowych, gromadzenie substancji garbnikowych). Dwie ostatnie grupy cech kseromorficznych obejmuja ponadto: zgrubienie zewnętrznej ściany komórek skórki, grubowarstwową kutykulę, występowanie wosku epikutykularnego oraz złogów węglanu wapnia. W sąsiedztwie ścian antyklinalnych w zewnętrznych ścianach komórek epidermy wykazano obecność mikrokanalików, które niewątpliwie zwiększają zdolność wyparowania wody w rozwijających się liściach roślin $K$. pumila w czasie wegetacji. Jednakże wyprodukowane na powierzchni liści osady wapienne chronią te organy w warunkach ekstremalnych. Cechy adaptacyjne występujące w strukturze liści $K$. pumila są konserwatywne i potwierdzają związek tego taksonu z warunkami występowania w ojczyźnie. 